\title{
THE BASTILLE
}

$A$ book in the series

Bicentennial Reflections on the French Revolution

General Editors: Keith Michael Baker, Stanford University

Steven Laurence Kaplan, Cornell University

The Cultural Origins of the French Revolution, Roger Chartier

Soldiers of the French Revolution, Alan Forrest

Revolutionary News: The Press in France, 1789-1799, Jeremy Popkin

A Rhetoric of Bourgeois Revolution:

The Abbe Sieyes and What Is the Third Estate?

William H. Sewell Jr. 



\section{THE BASTILLE}

\section{A HISTORY OF A SYMBOL OF DESPOTISM}

AND FREEDOM

Hans-Jürgen Lüsebrink and Rolf Reichardt

Translated by Norbert Schürer

Duke University Press

Durham and London

1997 
(C) 1997 Duke University Press

All rights reserved

Printed in the United States of America

on acid-free paper $\infty$

Originally published as Die "Bastille":

Zur Symbolgeschichte von Herrschaft und Freibeit

by Fischer Taschenbuch Verlag, $199^{\circ}$.

Library of Congress Cataloging-in-Publication

Data appear on the last printed page of this book.

Publication of this work was made possible by a grant from

Inter Nationes program for the promotion of translations of German books into universal languages. 